\title{
Migration, Urbanization And Its Implication On Food Security Among Low Income Households In Manzini City: Swaziland
}

\author{
Abul Salam \& Naeema Al Hosani \\ Faculty of Humanities and Social Science UAE University, Al Ain
}

\begin{abstract}
This paper seeks to contribute to recent food security debate. On the basis of field study conducted in three low income areas of Manzini, this study investigated how insufficient food has become a chronic development problem in Africa's urban area due to rapid urbanization which is eating up the resourceful land and pushing food production further away. Therefore this study was designed to capture the role of migration, urbanization and its implications on food security among the selected low income households in the area. Data for this study was collected through questionnaire interviews involving a sample of 500 households. Result show that very few households received food in the past years from rural based relatives and friends and even fewer received food from similar sources in urban areas. Contrary to what has been reported in the literature, in Manzini urban poverty has not strengthened urban-rural linkages in the form of increased food flows from rural areas. The study concludes that urban-rural linkages are not only important but are increasingly becoming an important element of livelihood strategies. Therefore this study recommends that there is a need to establish a background for understanding the complex and dynamic linkages between urbanization, migration and urban food security.
\end{abstract}

Keywords: Food security, Households, Livelihood, Migration, Urbanization

\section{INTRODUCTION}

Food security is a concept that has evolved during the 1990s far beyond a traditional focus on the supply of food at the national level (USAID 1995). The Levels of urban unemployment and urban poverty become visible to wider area of the continent of Africa. The right to food has been recognized by various international declarations, including the Universal Declaration of Human Rights (Jooma, 2005). As world food prices increase food insecurity threatens to dominate the humanitarian in 2011. As poor households struggle to meet urban expenses, the type, quantity and quality of food consumption tends to be an area of cut-back since it is not viewed as a fixed, absolute expense. Thus, households are thrust into food insecurity (Crush $e t$ al. 2006). Urban food insecurity problems arise on a large scale when urban growth is particularly rapid and especially when linked to distress migration (Webb and Rogers 2003).

Food security is no longer viewed as a failure to produce enough food nationally, but rather as a failure of livelihoods to provide adequate supply at the household level (Devereux and Maxwell 2001). This is due to the different factors which combine; the lack of food and lack of access to food intensify. The concept of food security includes the risk of not having access to needed food. These risks can be associated with variability in household income and food production. Thus, at the household level, food security is the ability of the household to secure enough food to ensure adequate dietary intake for all of its members (Bouis \& Hunt 1999).

Food security is achieved by having enough food present at all times in the community/nation to feed the population; households having the means for obtaining that food; individuals consuming a sufficient and balanced diet; and assurance that the three conditions will be met (ECS, 2005). The United Nations (UN) defines poverty as the denial of choices and opportunities for a tolerable life, lack of access to options and entitlements which are social, cultural, political, and environmental as well as economical (Gama, 2006). In Swaziland Food security is the adequate supply of food and food availability. This means stability of supplies and access to food and consumption by all. Food security is achieved when all people, at all times, have physical and economic access to sufficient safe and nutritious food to meet their dietary needs and food preferences for an active and healthy life (MOAC 2006). Unfortunately, a major problem in many developing countries remains the relative neglect of agriculture. Although the magnitude and rate of change vary by country, there is little doubt that more inhabitants of developing countries will be living in urban than rural areas within the next two decades. Urban food insecurity problems arise on a large scale when urban growth is particularly rapid and especially when linked to distress migration. While the problems of urban food insecurity are widely recognized, experiences of food-supported (Webb and Rogers 2003). 


\section{Food Insecurity in Africa}

The contribution of urban food cultivation to the food security of poor households in African cities has been recognized for many years (Crush et. al, 2010). Food crisis in Africa is continuing to worsen since1960s despite many effort by United Nations Food and Agricultural Organisation's (FAO) Freedom from Hunger Campaign, aimed at reducing food insecurity has failed in Africa. According to Mason, (2006) the figure for under nourishment is 17 percent, in sub-Saharan Africa the figure is 33 percent. For Central Africa it is 55 percent. On average the number of African food emergencies per year since the mid-1980s has tripled and the situation is not going to improve. Many of the commitment to halt hunger by 2015, as part of the Millennium Development Goals, will not be met by in Africa at current rates of progress.

Increasing poverty is a key factor in the food crises; food may be available but is simply unaffordable. Globally 1.4 billion people are absolutely poor, living below 1 US Dollar a day about 850 million people are hunger and around 6 million children die of malnutrition and suffer other disabilities. Most affected region is Sub-Saharan Africa where 31\% people are poor living below1 US Dollar a day (Braun 2008). Over the past two decades sub-Saharan Africa has had declining in farming and food aid from the West has been increased. The root cause of Africa's ongoing food insecurity is the lack of investment in agricultural sector. Sub-Saharan Africa has a predominantly rural economy, with 80 percent of the population living in rural areas and providing the livelihoods of the majority of the population. Another major factor in the food crisis is the increasing HIV/AIDS epidemic, which interacts with food insecurity. Around 25 million people have died from AIDS globally since the beginning of the epidemic on which 2.1 million only in 2008 by November and Sub-Saharan Africa being a leader with an estimated 1.9 million people were newly infected with HIV in sub-Saharan Africa in 2008 alone. There are approximately 33.4 million people infected with HIV in the world, of which about $67 \%$ live in Sub-Saharan Africa, majority of them with HIV and AIDS are women (61\%). According to UNAIDS, (2009) Swaziland has the highest HIV and AIDS prevalence rate in the world (26.4\%), and significantly higher than that of the sub-Saharan African region overall (7.5\%) and globally (1.1\%). Swaziland is also experiencing a major increase in child headed households as a result of the HIV and AIDS pandemic with 47\% of households being headed by children under the age of 15 years. This makes young people also vulnerable to poverty (UNDP, 2006). In 2008 HIV/AIDS was one of the greatest barriers to human development in Swaziland (Yasmin et. al 2010).

Maize production on communal farms fell significantly between 1992 and 2007, largely because of global climate change, AIDS-related illness and death. Research carried out by the British government's International Development Department on the effects of climate change in Africa predicts that by the year 2050 there will be severe changes in southern Africa, west and east Africa and as a result worsening food insecurity in Africa

\section{National Programme for Food Security in Swaziland}

To tackle the fear and opportunities relating to food security in Swaziland a National Programme for Food Security was set up in 2006, which include an integral part of the Comprehensive Agriculture Sector Policy and the National Development Strategy. According to the MOAC the Programme is complementary to National Food Security Policy which has introduced the status and framework of food security in line with the internationally accepted definition of food security. According to Dlamini et, al. (2010) in recent years there has been a growing realization that concerns of food security at aggregate level should be more to a concern on food security at a household level. Continued economic and political development in the country has raised a review of the strategies and roles of various stakeholders in the agriculture sector that work in collaboration in achieving food security objectives. The Programme was set out to tackle food insecurity and poverty reduction in the country. It follows the Policy in its framework arrangement around the four key pillars for food security, Food Availability, Food Access, Food Utilization and Nutritional Requirements; and Stability in Equitable Food Provision (MOAC 2006).

The main purpose of this Programme was to provide clear guidance regarding the strategies and measures that must be adopted in order to improve food security in Swaziland. At the same time, it must support related initiatives on reducing poverty, improving agricultural production and marketing, enhancing environmental management, strengthening disaster preparedness, improving health delivery and broadening access to water and sanitation (MOAC 2006). Currently Government of Swaziland is engaged in different activities such as formulating food security policies, action plans, and strategies upon food security, to insure the country's development.

Around $63 \%$ of Swaziland's people live below the poverty line, subsisting on US\$ 0.60 a day (WFP 2009 ), and $84 \%$ of the country's poor reside in rural areas and their per capita incomes are lower than those in urban areas (Tevera \& Matondo 2010). Life expectancy is the lowest in the world at 32.5 years. Swaziland is ranked as a lower middle income country, yet it is one of the countries affected by intense poverty (WFP 2009; Tevera $e t, a l .2010)$. A large proportion of the rural households practice subsistence agriculture and $66 \%$ of the 
rural population is unable to meet their basic food needs while $43 \%$ live in chronic poverty (Tevera \& Matondo 2010). Most of the rural population, including the poor lives on Swazi Nation Land where they farm small plots cultivating only maize under rain-fed agriculture. The rural economy is important, both at the household and community levels, for urban households. The creation of household food security is dependent on the availability of food at the market or community level and the ability of the household to access the available food. Food security refers to access to adequate and nutritious food for a healthy and productive life. Many SADC countries, such as Botswana, Lesotho, Mozambique and Swaziland, today are victims of the impact of food insecurity. For the past ten years, for instance, Swaziland has failed to achieve national food security, thereby resulting in considerable food shortages, especially in the lowveld part of the country. Food security in Swaziland has been related to maize production, yet cereal production has been declining since the 1980s. In addition, there has been a substantial increase in food prices, over 45\% from 1998 to 2005. This situation has eroded the ability of poor households and reduced their access to food (Tevera et, al.2010).

Swaziland's annual maize harvest in 2009 was estimated at 70,000 tons and is slightly more than the year is harvested. However, Swaziland had to import around 90,000 tons during April 2009 - March 2010 to meet the national cereal production shortfall (WFP, 2009). Per capita cereal consumption in Swaziland is 176kg./year (Edge, 2010). Results of the annual assessment by the Swaziland Vulnerability Assessment Committee (Swazi VAC) indicate that 116000 people faced a food deficit during the 2012/2013 lean season. This is a $30 \%$ increase on the 2011/2012 figure of 89000 (WFP, 2013). This is due to challenges faced by most maize farmers. The greatest impact of food insecurity, therefore, is seen more in developing countries than it is in developed countries. Therefore this study was designed to capture the role of migration, urbanization and its implications on food security among low income households in the study area.

\section{Research Method and Material}

\section{Study Area}

Swaziland (Figure 1) is a landlocked country found in Southern Africa, lying between latitude $25^{\circ} 39^{\prime}$ and $27^{\circ} 25^{\prime}$ south and between longitudes $32^{\circ} 10^{\prime}$ and $31048^{\prime}$ east (Mbuende, 1997). Swaziland shares a common border with Mozambique in the east and the Republic of South Africa in the west, south and north. The Manzini region in Swaziland is the largest and most prominent in the country. The urban population of the city of Manzini is estimated at over 35,000, while greater Manzini contains over 70,000 people (CSO 2007). The area is distinctly tropical and is characterized by high summer temperatures and low, but variable, rainfall between September and March. It is one of the hottest areas during the summer. Average summer temperatures for this region are between $28^{0} \mathrm{C}$ and $33^{\circ} \mathrm{C}$. This clearly shows that the area is amongst the hottest areas in Swaziland (Mbuendi, 1997). The city is faced with the challenge of mushrooming informal settlements, which strain the existing infrastructure, resulting in poor living standards and lack of employment for the majority of the residents. The city has both high and low income settlements. Social and demographic features of these settlements are different from the higher income suburbs of the city. Household sizes although lower than rural tend to rely on inconsistent sources of livelihood. Incomes are very low especially those headed by women (38.7\%). Data from the (2007) National census have conclusively shown that the majority of female-headed households are the poorest and tend to be larger. Women and children are the most disadvantaged and poor members of the society. In recent years, some of the informal settlements have been incorporated into the city. Three low income suburban areas of the city were selected for this study. These are Moneni, Ticancweni and Standini. Moneni area is situated on the eastern part of Manzini, and is four (4) kilometers from downtown. Ticancweni is a newer informal settlement which has been incorporated into the city, while Standini is an older suburb that has remained very impoverished for many years.

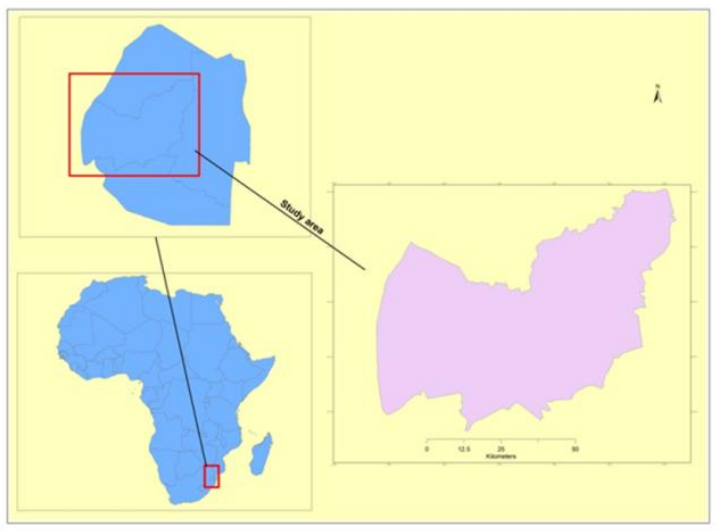

Figure: 1 Study Area 


\section{Method of data collection}

\section{Methodology}

Data for this study were collected from a wide variety of sources to present a description of the phenomenon or the experience from the perspectives of the respondents. In collecting the required data for the study a qualitative research approach was used. In the survey design used primary data collection methods included key informants interviews (the elderly and areas' authorities) and household surveys where household heads were interviewed. To collect data the study employed the structured interview technique of data collection, whereby the researcher interviewed the respondents face-to-face using a questionnaire. This method was found to be suitable for this study because it gave the researcher an opportunity to clarify the questions to the respondents and to observe the physical surroundings of the households as a way of verifying the responses. Instruments used included household survey questionnaires administered in each household to gather information on their resources, demographic and socio-economic characteristics and agricultural practices employed together with their perception to the phenomenon. The questionnaire comprised of both open-ended and closed ended questions. Key informants were interviewed through discussions which were guided by a discussion guide and an observation matrix was also used for observations made.

\section{Sample}

Household data from the Manzini City Council provided an empirical sampling frame which was used to determine the number of respondents to interview in the three low income areas in Moneni, Standini and Tincancweni. Systematic sampling was used within each area to select 500 households out of the total population of 2112 that were interviewed. Table 1 provides information on population size, number of households and sample size. In order to avoid unnecessary anxiety about the study, officials of the Manzini City Council were requested to inform the local leadership structures prior to the survey, that a team from the University of Swaziland would be in the area to interview them about urban food security issues.

\begin{tabular}{|l|l|l|l|l|}
\hline \multicolumn{6}{|l|}{ Table 1: Population Data, Sample Size and Sample Interval } \\
\hline Study area/site & $\begin{array}{l}\text { Population } \\
\text { size }\end{array}$ & No. of Households & Sample size & Sample interval \\
\hline Moneni & 3729 & 1071 & 250 & Skip -2 \\
\hline Tincancweni & 1374 & 390 & 150 & Skip -1 \\
\hline Standini & 660 & 201 & 100 & Skip -1 \\
\hline
\end{tabular}

Source of population data (2007 Swaziland Population and Housing Census)

\section{Rationale for Selecting Sites}

The three suburbs were selected on the basis of their socio-economic status. The study's basic assumption is that it is the low-income areas of the city where food insecurity is high. According to the 2008 vulnerability assessment for the Manzini region, the peri-urban corridor was one of the worst affected zones with 20,793 vulnerable people in terms of food deficit and required at least 2,878 metric tons of cereals or an expenditure deficit of SZL7, 316,558. Furthermore, all three communities have been incorporated into the city. However, the upgrading of the areas in terms of infrastructure is at a preliminary stage. In Moneni roads and street lighting are being upgraded while in the other two areas a lot still needs to be done.

\section{Data Presentation and Analysis}

The collected data was coded and analyzed using interpretational analysis. Interpretational analysis refers to examining data for constructs, themes and patterns that can be used to describe and explain phenomenon studied (Leedy, 1997). This means that the study interpreted the meaning of the results with regard to the questions it raised. The data was presented using graphs and tables.

\section{Demographic and Socio-economic Characteristics}

There were a total of 500 households sampled, with a total population of 2112 people. The proportion of the sampled population was $23.4 \%$ for Moneni, $38.5 \%$ for Ticancweni and $49.8 \%$ for Standini. The average household size was 4.2 and the largest household had 20 people.

\section{Research Findings And Analysis}

\section{Migration, Food Flows and Urban Food Security Rural - Urban Links}

A review of recent empirical evidence on migration and urbanization in Francophone West Africa suggests that economic crisis may increase circular migration between towns and villages (Devereux \& Maxwell, 2001). Although the magnitude and tempo of change may, vary by country. The result on figure 2 
shows that lifetime population movements were exceptionally high with $32 \%$, while Non-migrant households were $13 \%$ and $55 \%$ were mixed households.

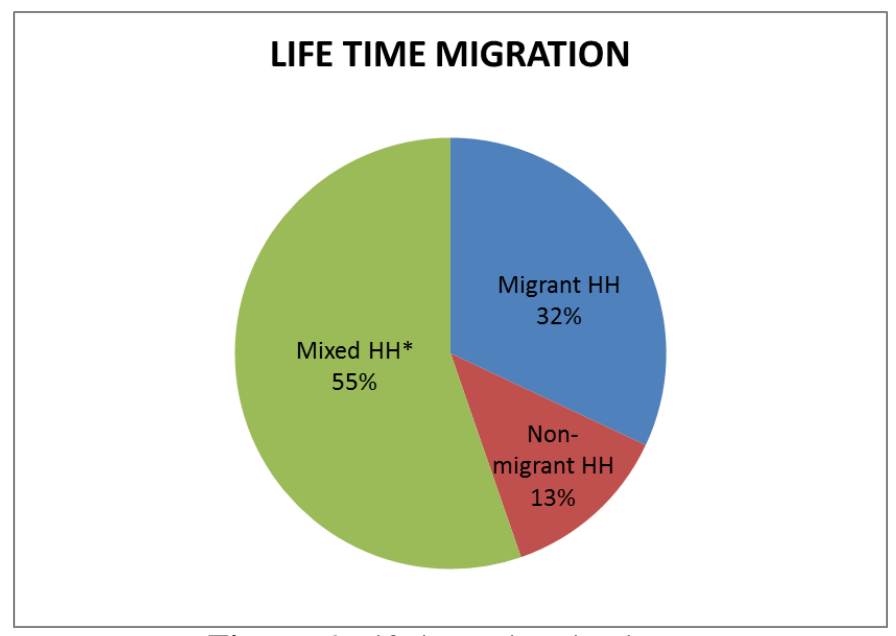

Figure: 2 Lifetime migration in \%

The food markets play an important role in household food security as changes in prices directly affects households with low purchasing power. In the face of declining supplies and increased demand for food to support households in the urban areas is very important. This logic is compounded by the fact that food is also declining as a share of total because of increasing number. This can be seen in figure 3 where only $35 \%$ households gets food transfer while majority of them $65 \%$ does not get food transfer from relative and friends.

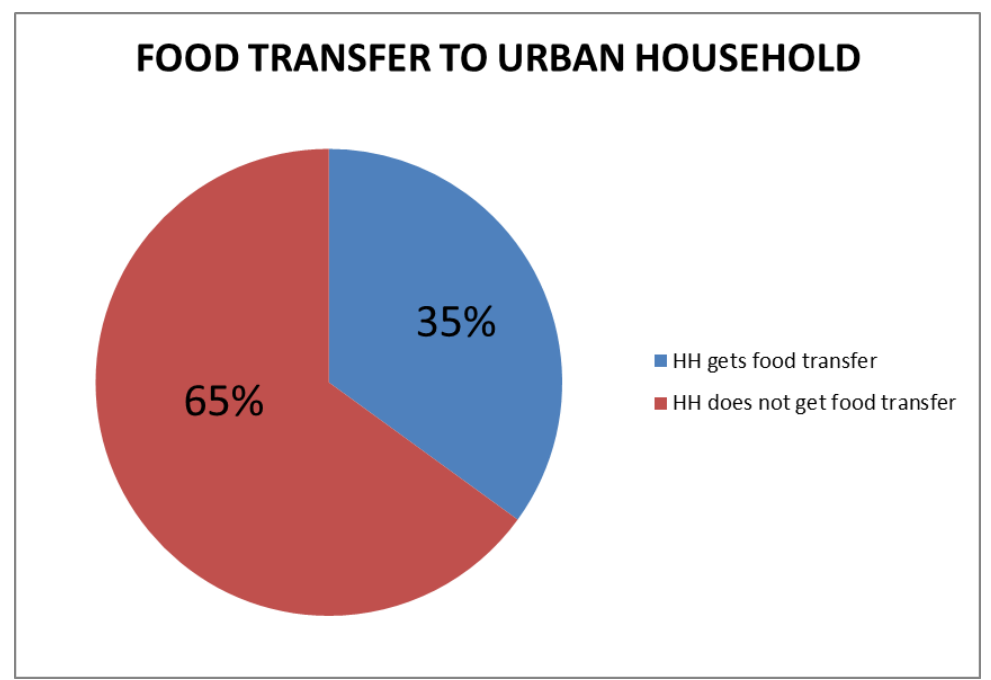

Figure: 3 Food transfers to urban households (Total transfers for all households)

One aspect of urban food security which has largely been ignored in the literature is that of urban food remittances from extended and immediate family in the rural areas. For example, table 2 shows that rural sources of food are important for migrant and non-migrant households in the Manzini city of Swaziland.

\begin{tabular}{|c|c|c|c|}
\hline & & $\mathrm{N}$ & $\%$ \\
\hline \multirow[t]{2}{*}{ Rural areas - Relatives } & Yes & 103 & 22.8 \\
\hline & No & 349 & 77.2 \\
\hline \multicolumn{2}{|l|}{ Total } & 452 & 100.0 \\
\hline \multirow[t]{3}{*}{ Rural areas - Friends } & Yes & 5 & 1.2 \\
\hline & No & 428 & 98.6 \\
\hline & Don't know & 1 & .2 \\
\hline \multicolumn{2}{|l|}{ Total } & 434 & 100.0 \\
\hline Urban areas - Relatives & Yes & 30 & 6.9 \\
\hline
\end{tabular}


Migration, Urbanization And Its Implication On Food Security Among Low Income Households.....

\begin{tabular}{|c|c|c|c|}
\hline & No & 403 & 92.9 \\
\hline & Don't know & 1 & .2 \\
\hline \multicolumn{2}{|l|}{ Total } & 434 & 100.0 \\
\hline \multirow[t]{2}{*}{ Urban areas - Friends } & Yes & 59 & 13.3 \\
\hline & No & 385 & 86.7 \\
\hline \multicolumn{2}{|l|}{ Total } & 444 & 100.0 \\
\hline \multirow{3}{*}{ Food links summarized } & Rural areas only & 92 & 52.9 \\
\hline & Urban areas only & 69 & 39.7 \\
\hline & Rural \& urban areas & 13 & 7.5 \\
\hline \multicolumn{2}{|l|}{ Total } & 174 & 100.0 \\
\hline
\end{tabular}

\section{Rural-Urban food Transfers}

Figure 4 shows that different types of food were supplied from rural areas but cereals (foods made from grain, which is staple food) were the most popular, with $57.7 \%$ of the households receiving cereals, $16 \%$ received vegetables, 9.1\% received food made from beans and nuts, $7.4 \%$ received roots or tubers, $4.6 \%$ received meat or poultry product, while the rest received other foods from rural areas. Urban dwellers have constantly maintained links with the rural areas due to economic decline and structural adjustment and thus rural links have become very important for urban people who are very vulnerable to financial fluctuations.

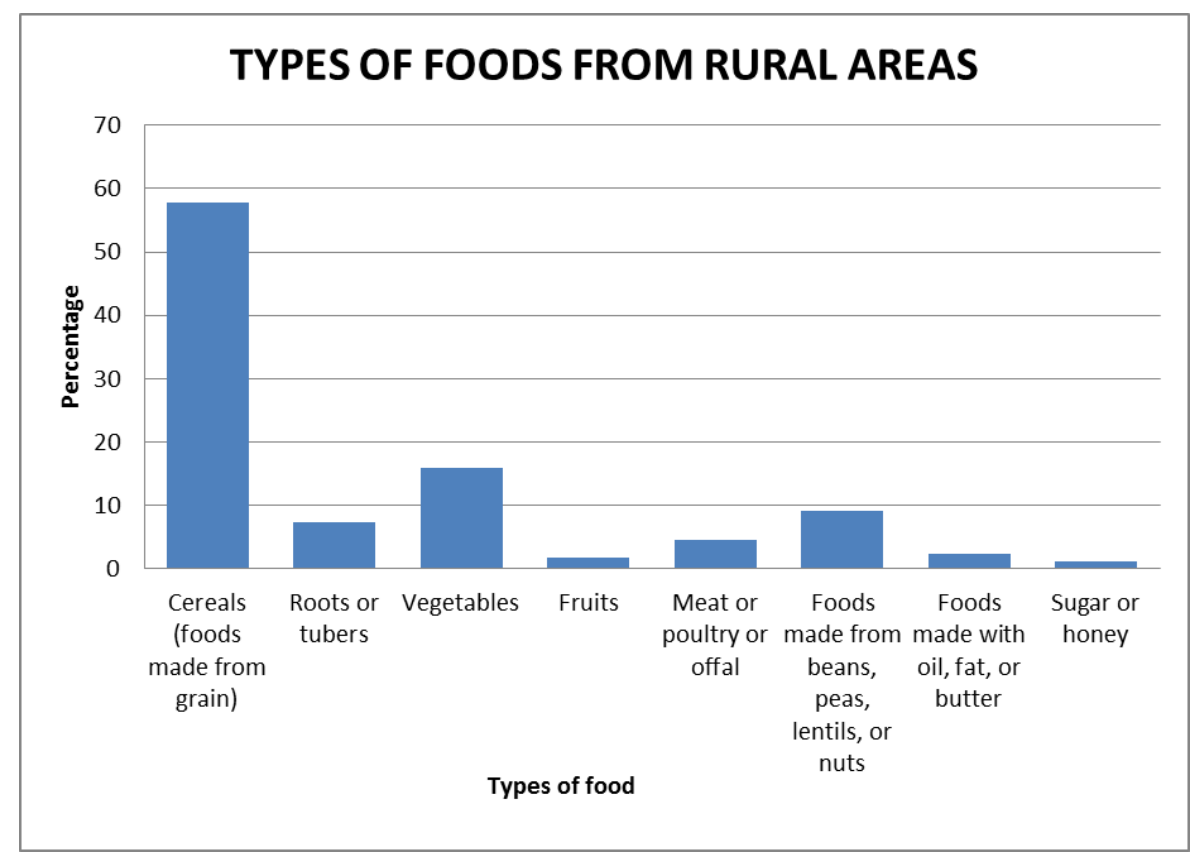

Figure: 4 Rural - Urban Food Transfers: Type of foods from rural areas

Table 3 clearly shows that households evenly received cereals, roots, vegetables, meat and foods made from beans, peas and lentils from rural areas. For example, $35.1 \%$ households received food at least once in two months, $30.9 \%$ received 3 to 6 times a year while 33\% received food once in a year and 1\% said they don't know. Table 3 also shows that $41.7 \%$ of the households received roots at least once in two months, $25 \%$ received 3 to 6 times a year while $25 \%$ once in a year and $8.3 \%$ said they don't know.

The table also shows that $44.4 \%$ households received vegetables at least once in two months, $22.2 \%$ received 3 to 6 times a year while $29.6 \%$ once in a year and 3.7\% said they don't know. As many as $66.7 \%$ said they received fruits at least once in 2 months. Again it can be seen from the table that $50 \%$ households received meat or poultry products at least once in two months, $12.5 \%$ received 3 to 6 times a year while $25 \%$ once a year and $12.5 \%$ said they don't know. The households also received foods made from beans, peas, lentils and nuts.

Table 3 shows that $31.3 \%$ of the respondents received foods from rural areas made from beans, peas, lentils and nuts at least once in two months, $18.8 \%$ received 3 to 6 times a year while $50 \%$ received only once in a year. On the other hand, $75 \%$ of the households said they received at least once in two months and $25 \%$ received at least once in a year food made with oil, fat or butter. While $50 \%$ households received sugar or honey once in two months, the rest of $50 \%$ received at least once in a year due to the fact that some of the food is seasonal and grown in certain time of the year. 
Migration, Urbanization And Its Implication On Food Security Among Low Income Households.....

\begin{tabular}{|l|l|l|l|l|l|l|l|l|l|l|}
\hline \multicolumn{2}{|l|}{ Table 3: Rural - Urban Food Transfers: Frequency of receiving food from rural areas } \\
\hline & $\begin{array}{l}\text { At least once } \\
\text { every 2 } \\
\text { months }\end{array}$ & $\begin{array}{l}\text { 3-6 times a } \\
\text { year }\end{array}$ & $\begin{array}{l}\text { At least } \\
\text { once a year }\end{array}$ & $\begin{array}{l}\text { Don't } \\
\text { know }\end{array}$ & Total \\
\hline & $\mathrm{N}$ & $\%$ & $\mathrm{~N}$ & $\%$ & $\mathrm{~N}$ & $\%$ & $\mathrm{~N}$ & $\%$ & $\mathrm{~N}$ & $\%$ \\
\hline $\begin{array}{l}\text { Cereals ffoods made from } \\
\text { grain) }\end{array}$ & 34 & 35.1 & 30 & 30.9 & 32 & 33.0 & 1 & 1.0 & 97 & 100.0 \\
\hline Roots or tubers & 5 & 41.7 & 3 & 25.0 & 3 & 25.0 & 1 & 8.3 & 12 & 100.0 \\
\hline Vegetables & 12 & 44.4 & 6 & 22.2 & 8 & 29.6 & 1 & 3.7 & 27 & 100.0 \\
\hline Fruits & 2 & 66.7 & 0 & .0 & 0 & .0 & 1 & 33.3 & 3 & 100.0 \\
\hline Meat or poultry or offal & 4 & 50.0 & 1 & 12.5 & 2 & 25.0 & 1 & 12.5 & 8 & 100.0 \\
\hline $\begin{array}{l}\text { Foods made from beans, peas, } \\
\text { lentils, or nuts }\end{array}$ & 5 & 31.3 & 3 & 18.8 & 8 & 50.0 & 0 & .0 & 16 & 100.0 \\
\hline $\begin{array}{l}\text { Foods made with oil, fat, or } \\
\text { butter }\end{array}$ & 3 & 75.0 & 0 & .0 & 1 & 25.0 & 0 & .0 & 4 & 100.0 \\
\hline Sugar or honey & 1 & 50.0 & 0 & .0 & 1 & 50.0 & 0 & .0 & 2 & 100.0 \\
\hline
\end{tabular}

\section{Intra and Inter-Urban Food Transfers}

Figure 5 shows that $20.2 \%$ of the households had received food from relatives and friends based in urban areas. The figure also shows that $39 \%$ of the households received cereals, $18.1 \%$ received vegetables, $10 \%$ households received sugar or honey, and $8.2 \%$ received meat or poultry.

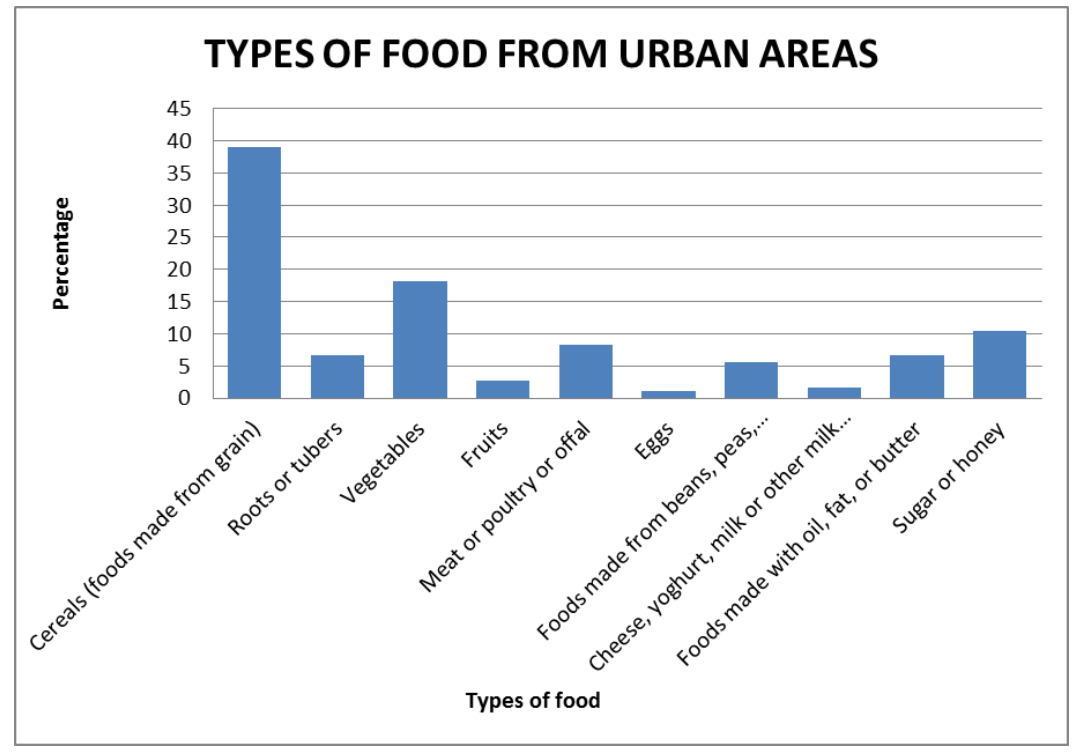

Figure 5: Types of foods received from urban areas

Table 4 shows how frequently households had received food from urban areas. It clearly shows that $36.2 \%$ of the households received cereals at once in a week, $50.7 \%$ at least once in two months, $4.3 \% 3-6$ times in a year, $5.8 \%$ at least once in a year and the rest said they don't know. It can also be seen from table 8 that $33.3 \%$ of the households received roots or tubers at least once a week, $25 \%$ at least once in two months, 25\% 36 times in a year, $8.3 \%$ at least once in a year and the rest of them said they don't know.

According to table $45,43.8 \%$ of the households received vegetables at least once in a week, $43.8 \%$ at least once in two months, $3.1 \%$ at least once in a year and the rest of them said they don't know. Table 4 shows that $80 \%$ of the households received fruits at least once in two months, $33.3 \%$ of the households received meat at least once in a week, $46 \%$ at least once in two months, 13.3\% 3-6 times in a year, and the rest of them said they don't know. Table 4 further shows that $40 \%$ of the households received foods made from beans, peas and lentils at least once in a week, $40 \%$ at least once in two months, $10 \%$ at least once in a year and the rest of them said they don't know. 
Migration, Urbanization And Its Implication On Food Security Among Low Income Households.....

\begin{tabular}{|c|c|c|c|c|c|c|c|c|c|c|c|c|}
\hline & \multicolumn{2}{|c|}{$\begin{array}{c}\text { At least } \\
\text { once a week }\end{array}$} & \multicolumn{2}{|c|}{$\begin{array}{c}\text { At least } \\
\text { once every } 2 \\
\text { months }\end{array}$} & \multicolumn{2}{|c|}{$\begin{array}{c}\text { 3-6 times a } \\
\text { year }\end{array}$} & \multicolumn{2}{|c|}{$\begin{array}{c}\text { At least } \\
\text { once a } \\
\text { year }\end{array}$} & \multicolumn{2}{|c|}{ Don't know } & \multicolumn{2}{|c|}{ Total } \\
\hline & $\mathrm{N}$ & $\%$ & $\mathrm{~N}$ & $\%$ & $\mathrm{~N}$ & $\%$ & $\mathrm{~N}$ & $\%$ & $\mathrm{~N}$ & $\%$ & $\mathrm{~N}$ & $\%$ \\
\hline $\begin{array}{l}\text { Cereals (foods } \\
\text { made from grain) }\end{array}$ & 25 & 36.2 & 35 & 50.7 & 3 & 4.3 & 4 & 5.8 & 2 & 2.9 & 69 & $\overline{100.0}$ \\
\hline Roots or tubers & 4 & 33.3 & 3 & 25.0 & 3 & 25.0 & 1 & 8.3 & 1 & 8.3 & 12 & 100.0 \\
\hline Vegetables & 14 & 43.8 & 14 & 43.8 & 0 & .0 & 1 & 3.1 & 3 & 9.4 & 32 & 100.0 \\
\hline Fruits & 0 & .0 & 4 & 80.0 & 0 & .0 & 0 & .0 & 1 & 20.0 & 5 & 100.0 \\
\hline $\begin{array}{l}\text { Meat or poultry or } \\
\text { offal }\end{array}$ & 5 & 33.3 & 7 & 46.7 & 2 & 13.3 & 0 & .0 & 1 & 6.7 & 15 & 100.0 \\
\hline Eggs & 0 & .0 & 1 & 50.0 & 1 & 50.0 & 0 & .0 & 0 & .0 & 2 & 100.0 \\
\hline $\begin{array}{l}\text { Fresh or dried fish } \\
\text { or shellfish }\end{array}$ & 0 & .0 & 0 & .0 & 0 & .0 & 0 & .0 & 0 & .0 & 0 & .0 \\
\hline $\begin{array}{l}\text { Foods made from } \\
\text { beans, peas, lentils, } \\
\text { or nuts }\end{array}$ & 4 & 40.0 & 4 & 40.0 & 0 & .0 & 1 & $\begin{array}{l}10 . \\
0\end{array}$ & 1 & 10.0 & 10 & 100.0 \\
\hline $\begin{array}{l}\text { Cheese, yoghurt, } \\
\text { milk or other milk } \\
\text { products }\end{array}$ & 1 & 33.3 & 1 & 33.3 & 1 & 33.3 & 0 & .0 & 0 & .0 & 3 & 100.0 \\
\hline $\begin{array}{l}\text { Foods made with } \\
\text { oil, fat, or butter }\end{array}$ & 4 & 33.3 & 7 & 58.3 & 0 & .0 & 0 & .0 & 1 & 8.3 & 12 & 100.0 \\
\hline Sugar or honey & 10 & 52.6 & 8 & 42.1 & 0 & .0 & 1 & 5.3 & 0 & .0 & 19 & 100.0 \\
\hline
\end{tabular}

Table 4 shows that $33.3 \%$ of the households received cheese yoghurt, milk or milk product at least once in a week, $33.3 \%$ at least once in two months, 33.3\% 3-6 times in a year. 33.3\% received food made with oil at least once in a week, 58.3\% at least once in two months and the rest of them said they don't know. 52.6\% had received sugar or honey at least once in a week and $42.1 \%$ had received at least once in two months and $5.3 \%$ had received at least once in a year from urban areas

The rural economy is important, both at the household and community levels, for urban households. The creation of household food security is dependent on the availability of food at the market or community level and the ability of the household to access the available food. Food security refers to access to adequate and nutritious food for a healthy and productive life. Many SADC countries, such as Botswana, Lesotho, Mozambique and Swaziland, today are victims of the impact of food insecurity. For the past ten years, for instance, Swaziland has failed to achieve national food security, thereby resulting in considerable food shortages, especially in the lowveld part of the country. The greatest impact of food insecurity, therefore, is seen more in developing countries than it is in developed countries. Figure 6 shows that $53 \%$ of the households believed that it is very important to receive food from rural or urban areas, $32 \%$ believed that it is important, $6.5 \%$ believed it is critical to their survival and lastly, $7.7 \%$ believed it is somewhat important. In other words, the entire sampled urban households realize that this is a part of their livelihood to receive food from different sources.

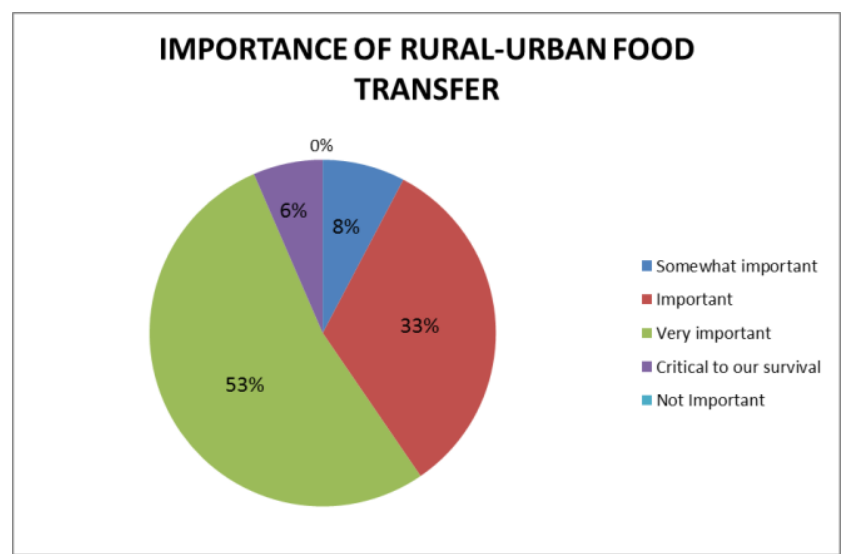

Figure 6: Importance of Rural - Urban Food Transfers 
Migration, Urbanization And Its Implication On Food Security Among Low Income Households.....

\section{Migrancy Status of Households Food Security by HFIAP Scale}

Urban food insecurity problems occur on a large scale when urban expansion is predominantly rapid and especially when linked to agony migration. The search for food security by migrants may also have important implications on country's demographic situation. The poverty situation in Swaziland conforms that impacts on the country have been complex. Table 5 shows that $22.5 \%$ migrant household were food secure, $12.5 \%$ non-migrant household were food secure while majority $65 \%$ of mixed household were food secure. Table again show that majority of mixed household $54.5 \%$ were food insecure while $32.8 \%$ of migrant household were food insecure and $12.7 \%$ of non-migrant household were food insecure. The variation in the percentages depends on the actual number of the household.

\begin{tabular}{|l|l|l|}
\hline Table:5 Migrant & \multicolumn{2}{l|}{ households by Household Food Security Status } \\
\hline Food secure & Migrant HH & \% \\
\cline { 2 - 3 } & Non-Migrant HH & 22.5 \\
\cline { 2 - 3 } & Mixed HH & 12.5 \\
\cline { 2 - 3 } & Total & 65.0 \\
\hline Food insecure & Migrant HH & $\mathbf{1 0 0 . 0}$ \\
\cline { 2 - 3 } & Non-Migrant HH & 32.8 \\
\cline { 2 - 3 } & Mixed HH & 12.7 \\
\cline { 2 - 3 } & Total & 54.5 \\
\hline Total & Migrant HH & $\mathbf{1 0 0 . 0}$ \\
\cline { 2 - 3 } & Non-Migrant HH & 32.0 \\
\cline { 2 - 3 } & Mixed HH & 12.7 \\
\cline { 2 - 3 } & Total & 55.3 \\
\hline
\end{tabular}

The biggest response to increased urban poverty involves the escalation and alteration of the urbanrural linkages which has always been an important part of urbanization processes in Africa. However, little attention has been given to wider spatial aspects of urban livelihoods (Tacoli 2002). As illustrated in Table 6, only $5.7 \%$ of the households (both migrant and non-migrant) are food secure, while $2.5 \%$ are mildly insecure, $12.5 \%$ are moderately insecure while the majority $(79.3 \%)$ is severely food insecure. The small number of migrant households makes it difficult to determine whether migrant households are more food secure than nonmigrant households. However, it is important to note that only $2.6 \%$ of the migrant households are food secure as compared to $6.0 \%$ of the non-migrant households. Surprisingly, $76.9 \%$ of migrant households are severely food insecure as compared to $79.6 \%$ of the non-migrant households.

\begin{tabular}{|l|l|l|l|l|l|l|l|l|l|l|l|}
\hline Table 6: Migrancy status of HH (By HFIAP scale) \\
\hline & $\begin{array}{l}\text { Food } \\
\text { secure }\end{array}$ & $\begin{array}{l}\text { Mildly } \\
\text { insecure }\end{array}$ & $\begin{array}{l}\text { Moderately } \\
\text { insecure }\end{array}$ & \multicolumn{2}{l|}{$\begin{array}{l}\text { Severely } \\
\text { insecure }\end{array}$} & \multicolumn{2}{|l|}{ Total } \\
\hline & $\mathrm{N}$ & $\%$ & $\mathrm{~N}$ & $\%$ & $\mathrm{~N}$ & $\%$ & $\mathrm{~N}$ & $\%$ & $\mathrm{~N}$ & $\%$ \\
\hline & 1 & 2.6 & 1 & 2.6 & 7 & 17.9 & 30 & 76.9 & 39 & 100.0 \\
\hline $\begin{array}{l}\text { Migrant HH } \\
\text { HH }\end{array}$ & 27 & 6.0 & 11 & 2.4 & 54 & 12.0 & 358 & 79.6 & 450 & 100.0 \\
\hline Total & $\mathbf{2 8}$ & $\mathbf{5 . 7}$ & $\mathbf{1 2}$ & $\mathbf{2 . 5}$ & $\mathbf{6 1}$ & $\mathbf{1 2 . 5}$ & $\mathbf{3 8 8}$ & $\mathbf{7 9 . 3}$ & $\mathbf{4 8 9}$ & $\mathbf{1 0 0 . 0}$ \\
\hline
\end{tabular}

\section{Rural - Urban Links}

Table 7 shows that only 102 out of 442 households received food in the past years from rural based relatives due to decline in agricultural production and only $3.9 \%$ of these households were food secure. Not surprisingly, all of the 5 households that received food from friends in the rural areas were moderately and severely insecure. Only 30 out of 424 households received food in the past years from urban relatives in the urban areas and just $3.3 \%$ of them were food secure while $93.3 \%$ were severely food insecure. On the other hand, 57 out of 424 households received food from friends in the urban areas and only $7 \%$ of these were food secure while $86 \%$ severely insecure.

One of the responses to the increased urban poverty involves the strengthening and adaptation of the urban-rural linkages that have always been such an important part of urbanization processes in sub-Saharan Africa (Potts and Mutambirwa, 1990). Access to food for poor urban households remains a very serious issue. As urban poor households fight to meet urban expenses, quantity and quality of food consumption tends to be an area of cut-back (Crush. et, al. 2006). Migrant households have constantly maintained the strong links with the rural areas. 
Migration, Urbanization And Its Implication On Food Security Among Low Income Households.....

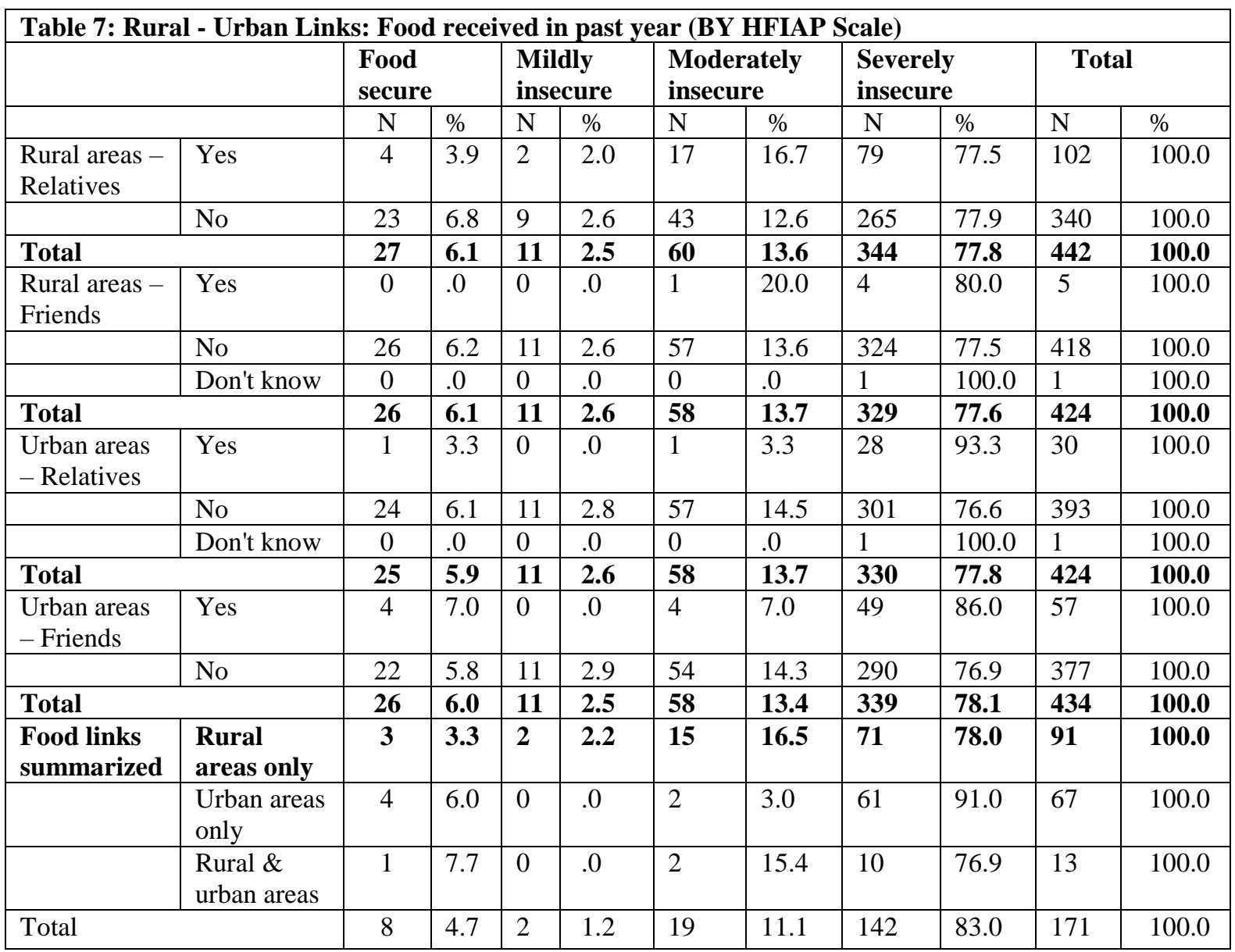

Table 8 shows rural-urban food transfers using the HFIAP scale according to type of food. That by HFIAP scale $58.1 \%$ of households were received cereals from rural areas. While $7 \%$ received roots or tubers, $15.7 \%$ vegetables, $1.7 \%$ fruits, $4.7 \%$ meat or poultry or offal, $9.3 \%$ food made from beans, $2.3 \%$ foods made with oil, fat or butter and 1.2 sugar or honey. Table 9 shows that food secure households received cereals only from rural areas while food insecure households received a wide range of foods, including roots, vegetables, fruits, meat/poultry and foods made from beans, peas, lentils or nuts. Among the severely food insecure households, cereals, vegetables and foods made from beans, peas, lentils or nuts, were the main foods received.

\begin{tabular}{|l|l|l|l|l|l|l|l|l|l|l|l|l|l|}
\hline Table 8: Rural - Urban Food Transfers: Type of foods from rural areas (By HFIAP Scale) \\
\hline & \multicolumn{2}{|l|}{ Food secure } & \multicolumn{2}{l}{$\begin{array}{l}\text { Mildly } \\
\text { insecure }\end{array}$} & \multicolumn{2}{l}{$\begin{array}{l}\text { Moderately } \\
\text { insecure }\end{array}$} & \multicolumn{2}{l}{$\begin{array}{l}\text { Severely } \\
\text { insecure }\end{array}$} & \multicolumn{2}{l|}{ Total } \\
\hline & R & CR \% & R & CR \% & R & CR \% & R & CR \% & R & CR \% \\
\hline Cereals (foods made from grain) & 4 & 100.0 & 2 & 50.0 & 15 & 53.6 & 79 & 58.1 & 100 & 58.1 \\
\hline Roots or tubers & 0 & .0 & 1 & 25.0 & 3 & 10.7 & 8 & 5.9 & 12 & 7.0 \\
\hline Vegetables & 0 & .0 & 0 & .0 & 5 & 17.9 & 22 & 16.2 & 27 & 15.7 \\
\hline Fruits & 0 & .0 & 0 & .0 & 1 & 3.6 & 2 & 1.5 & 3 & 1.7 \\
\hline Meat or poultry or offal & 0 & .0 & 0 & .0 & 1 & 3.6 & 7 & 5.1 & 8 & 4.7 \\
\hline $\begin{array}{l}\text { Foods made from beans, peas, } \\
\text { lentils, or nuts }\end{array}$ & 0 & .0 & 1 & 25.0 & 1 & 3.6 & 14 & 10.3 & 16 & 9.3 \\
\hline $\begin{array}{l}\text { Foods made with oil, fat, or } \\
\text { butter }\end{array}$ & 0 & .0 & 0 & .0 & 1 & 3.6 & 3 & 2.2 & 4 & 2.3 \\
\hline Sugar or honey & 0 & .0 & 0 & .0 & 1 & 3.6 & 1 & .7 & 2 & 1.2 \\
\hline Total & $\mathbf{4}$ & $\mathbf{1 0 0 . 0}$ & $\mathbf{4}$ & $\mathbf{1 0 0 . 0}$ & $\mathbf{2 8}$ & $\mathbf{1 0 0 . 0}$ & $\mathbf{1 3 6}$ & $\mathbf{1 0 0 . 0}$ & $\mathbf{1 7 2}$ & $\mathbf{1 0 0 . 0}$ \\
\hline
\end{tabular}

\section{Rural - Urban Food Transfers}

The analysis of food insecurity is mainly focused upon risk factors and whether households can cope with shortfalls. In the city, this revolves around access to cash for food and basic necessities, which is tied directly to 
wages and prices, but also includes environmental factors such as overcrowding, an unhygienic environment and the lack of a functional safety net. Food prices are integral to the food security of urban dwellers (Crush, $e t$, al. 2006).

\begin{tabular}{|l|l|l|l|l|l|l|l|l|l|}
\hline Table 9: Rural - Urban Food transfers: Type of foods from URBAN areas (By HFIAP Scale) \\
\hline & \multicolumn{2}{|l|}{ Food secure } & \multicolumn{2}{l}{$\begin{array}{l}\text { Moderately } \\
\text { insecure }\end{array}$} & \multicolumn{2}{l|}{$\begin{array}{l}\text { Severely } \\
\text { insecure }\end{array}$} & \multicolumn{2}{l|}{ Total } \\
\hline & $\mathrm{R}$ & $\mathrm{CR} \%$ & $\mathrm{R}$ & $\mathrm{CR} \%$ & $\mathrm{R}$ & $\mathrm{CR} \%$ & $\mathrm{R}$ & CR \% \\
\hline Cereals (foods made from grain) & 4 & 44.4 & 2 & 28.6 & 64 & 39.8 & 70 & 39.5 \\
\hline Roots or tubers & 0 & .0 & 0 & .0 & 11 & 6.8 & 11 & 6.2 \\
\hline Vegetables & 2 & 22.2 & 3 & 42.9 & 26 & 16.1 & 31 & 17.5 \\
\hline Fruits & 0 & .0 & 0 & .0 & 5 & 3.1 & 5 & 2.8 \\
\hline Meat or poultry or offal & 1 & 11.1 & 0 & .0 & 14 & 8.7 & 15 & 8.5 \\
\hline Eggs & 0 & .0 & 0 & .0 & 2 & 1.2 & 2 & 1.1 \\
\hline Foods made from beans, peas, lentils, or nuts & 0 & .0 & 0 & .0 & 10 & 6.2 & 10 & 5.6 \\
\hline Cheese, yoghurt, milk or other milk products & 1 & 11.1 & 0 & .0 & 2 & 1.2 & 3 & 1.7 \\
\hline Foods made with oil, fat, or butter & 0 & .0 & 0 & .0 & 11 & 6.8 & 11 & 6.2 \\
\hline Sugar or honey & 1 & 11.1 & 2 & 28.6 & 16 & 9.9 & 19 & 10.7 \\
\hline Total & $\mathbf{9}$ & $\mathbf{1 0 0 . 0}$ & $\mathbf{7}$ & $\mathbf{1 0 0 . 0}$ & $\mathbf{1 6 1}$ & $\mathbf{1 0 0 . 0}$ & $\mathbf{1 7 7}$ & $\mathbf{1 0 0 . 0}$ \\
\hline
\end{tabular}

As shown in table 9 by the HFIAP scale, $39.5 \%$ of the households received cereals from urban areas. While $6.2 \%$ received roots or tubers, $17.5 \%$ vegetables, $2.8 \%$ fruits, $8.5 \%$ meat or poultry or offal, $5.6 \%$ food made from beans, $1.7 \%$ cheese, yoghurt, milk or other milk product, $6.2 \%$ foods made with oil, fat or butter and 10.7 sugar or honey.

\section{Migrancy Status of Households and Rural-Urban Links by the Average Food Security Score}

Table 10 show the household food security status of the household in the study area where majority $94.2 \%$ of the households were food insecure while $5.8 \%$ were food secure.

\begin{tabular}{|l|l|l|}
\hline \multicolumn{3}{|l|}{$\begin{array}{l}\text { Table1 10 Food transfers to urban households by Household } \\
\text { Food Security Status (Count and \% of receiving households) }\end{array}$} \\
\hline & $\boldsymbol{N}$ & $\mathbf{\%}$ \\
\hline Food secure & 10 & 5.8 \\
\hline Food insecure & 161 & 94.2 \\
\hline Total & $\mathbf{1 7 1}$ & $\mathbf{1 0 0 . 0}$ \\
\hline
\end{tabular}

Urban food insecurity problems arise on a large scale when urban growth is particularly rapid and especially when linked to distress migration (Webb and Rogers 2003). Table 11 below shows average food insecurity scores by HFIAS score. Non migrant households have a low score (14.73) and are food secure while migrant households have high score (16.38) and are food insecure. On the other hand, the HDD score shows that migrant households have high (4.47) and are more diverse while non-migrant have a low score (4.06) and are less diverse. The MAHFP score also indicates that migrant households have a higher score (4.77) that non migrant household (4.68) and are generally food insecure. In general, rural-urban migration has been thought to improve the personal food security of the individual migrant.

\begin{tabular}{|l|r|r|r|r|r|r|r|r|}
\hline \multicolumn{2}{|l|}{ Table 11: Migrancy Status of HH BY Average Food Insecurity Scores } \\
\hline & \multicolumn{2}{|c|}{ HFIAS Score } & \multicolumn{2}{|c|}{ HDD Score } & MAHFP Indicator & $\begin{array}{c}\text { MAHFP Indicator } \\
\text { Food Insecure } \\
\text { Only) }\end{array}$ \\
\hline & $\mathrm{N}$ & Average & $\mathrm{N}$ & Average & $\mathrm{N}$ & Average & $\mathrm{N}$ & Average \\
\hline Migrant HH & $\mathrm{N}=39$ & 16.38 & $\mathrm{~N}=36$ & 4.47 & $\mathrm{~N}=37$ & 5.95 & $\mathrm{~N}=31$ & 4.77 \\
\hline $\begin{array}{l}\text { Non-migrant } \\
\text { HH }\end{array}$ & $\mathrm{N}=450$ & 14.73 & $\mathrm{~N}=442$ & 4.06 & $\mathrm{~N}=443$ & 5.87 & $\mathrm{~N}=371$ & 4.68 \\
\hline
\end{tabular}

Urban-rural interactions are not a new phenomenon in Africa. There are important differences in household food security issues in the rural and urban contexts. In urban areas, household food security is primarily a function. The unsanitary health environment in poor urban areas and high population densities 
makes the urban food security situation sometimes qualitatively different as compared with the rural situation of the real wage rate (that is, relative to food prices) and the level of employment (Bouis.\& Hunt1999).

\begin{tabular}{|c|c|c|c|c|c|c|c|c|c|}
\hline & \multicolumn{2}{|c|}{ HFIAS Score } & \multicolumn{2}{|c|}{ HDD Score } & \multicolumn{2}{|c|}{ MAHFP Indicator } & \multicolumn{2}{|c|}{$\begin{array}{l}\text { MAHFP Indicator } \\
\text { (Food Insecure } \\
\text { Only) }\end{array}$} \\
\hline & & $\mathrm{N}$ & $\begin{array}{c}\text { Averag } \\
\mathrm{e}\end{array}$ & $\mathrm{N}$ & $\begin{array}{c}\text { Avera } \\
\text { ge }\end{array}$ & $\mathrm{N}$ & Average & $\mathrm{N}$ & Average \\
\hline \multirow[t]{2}{*}{$\begin{array}{l}\text { Rural areas - } \\
\text { Relatives }\end{array}$} & Yes & $\mathrm{N}=102$ & 14.10 & $\mathrm{~N}=98$ & 4.29 & $\mathrm{~N}=100$ & 6.47 & $\mathrm{~N}=85$ & 5.49 \\
\hline & No & $\mathrm{N}=340$ & 14.80 & $\mathrm{~N}=336$ & 4.11 & $\mathrm{~N}=337$ & 5.53 & $\mathrm{~N}=274$ & 4.04 \\
\hline \multirow[t]{2}{*}{$\begin{array}{l}\text { Rural areas - } \\
\text { Friends }\end{array}$} & Yes & $\mathrm{N}=5$ & 17.60 & $\mathrm{~N}=5$ & 6.20 & $\mathrm{~N}=5$ & 7.20 & $\mathrm{~N}=4$ & 6.00 \\
\hline & No & $\mathrm{N}=418$ & 14.57 & $\mathrm{~N}=413$ & 4.11 & $\mathrm{~N}=414$ & 5.71 & $\mathrm{~N}=341$ & 4.37 \\
\hline \multirow[t]{2}{*}{$\begin{array}{l}\text { Urban areas } \\
\text { - Relatives }\end{array}$} & Yes & $\mathrm{N}=30$ & 17.67 & $\mathrm{~N}=30$ & 3.87 & $\mathrm{~N}=30$ & 4.73 & $\mathrm{~N}=25$ & 3.28 \\
\hline & No & $\mathrm{N}=393$ & 14.43 & $\mathrm{~N}=389$ & 4.16 & $\mathrm{~N}=389$ & 5.82 & $\mathrm{~N}=320$ & 4.48 \\
\hline \multirow[t]{2}{*}{$\begin{array}{l}\text { Urban areas } \\
\text { - Friends }\end{array}$} & Yes & $\mathrm{N}=57$ & $\begin{array}{l}15.79 \\
\end{array}$ & $\mathrm{~N}=55$ & 3.91 & $\mathrm{~N}=57$ & 5.53 & $\mathrm{~N}=49$ & 4.47 \\
\hline & No & $\mathrm{N}=377$ & 14.56 & $\mathrm{~N}=372$ & 4.16 & $\mathrm{~N}=371$ & 5.81 & $\mathrm{~N}=304$ & 4.44 \\
\hline \multirow[t]{3}{*}{$\begin{array}{l}\text { Food links } \\
\text { summarized }\end{array}$} & $\begin{array}{l}\text { Rural areas } \\
\text { only }\end{array}$ & $\mathrm{N}=91$ & 14.29 & $\mathrm{~N}=87$ & 4.14 & $\mathrm{~N}=89$ & 6.51 & $\mathrm{~N}=76$ & 5.57 \\
\hline & $\begin{array}{l}\text { Urban } \\
\text { areas only }\end{array}$ & $\mathrm{N}=67$ & 17.00 & $\mathrm{~N}=65$ & 3.54 & $\mathrm{~N}=67$ & 4.91 & $\mathrm{~N}=59$ & 3.95 \\
\hline & $\begin{array}{l}\text { Rural \& } \\
\text { urban } \\
\text { areas }\end{array}$ & $\mathrm{N}=13$ & 12.85 & $\mathrm{~N}=13$ & 5.54 & $\mathrm{~N}=13$ & 6.62 & $\mathrm{~N}=10$ & 5.00 \\
\hline
\end{tabular}

Table 12 shows the strong link between rural and urban areas and average food insecurity scores. It can be seen clearly in table 12 that those who received food from rural areas relatives has a better score (14.10) and food secure by HFIAS score than those who received food from rural areas friend have (17.60) and are food insecure. On the other hand in urban areas is the vice versa those who received food from urban areas friends have better score (15.79) than those who received food from urban areas relatives have (17.67) score. But HDDS score shows that those who received food from rural areas friends have better (6.20) score than those who received food from rural relatives have low (4.29) score and are less diverse. While those who received the food from urban friends have slightly better (3.91) score than those who received from urban relatives have (3.87) score and are food insecure.

MAHFP indicator shows that those who received from rural areas friends are more food secure with (7.20) score than those who received from rural relatives with (6.47) score and are food insecure. Those who received the food from urban friends have better (5.53) score than those who received from urban relatives have (4.73) score and are food insecure. MAHFP indicator for food insecure only shows that those who received from rural areas friends are more food secure with (6.00) score than those who received from rural relatives with (5.49) score and are food insecure. Those who received the food from urban friends have better (4.47) score than those who received from urban relatives have (3.28) score and are food insecure. Food transfers are vital to urban food security at the household level. In general, rural-urban migration has been thought to improve the personal food security of the individual migrant as well as social relations.

\section{CONCLUSIONS AND POLICY RECOMMENDATIONS}

Poverty is a key factor behind the high food insecurity levels among households in Manzini. This partly explains why in urban areas like Manzini poor households are likely to be food insecure as they do not have a cash income to purchase sufficient food. While the study could not address all pertinent issues in the food security and health debate, it has been able to provide a case study of the urban situation for low-income community in one municipality. Save the Children (2004:36) has argued that "household economy analysis can provide information on the nature and scale of poverty across a community, of the specific characteristics of HIV affected households and can give a good indication of the potential range and cost of interventions that would assist different categories of poor households. 
Several findings emerge from the study. First, although the majority of the households worried over enough food to eat, may not be able to eat what they wanted, or ate what they did not want because of lack of resources, in general, their levels of food security was not so bad as most had something to eat.

Second, based on the LPI scores on the categories analyzed, the food security situation of the urban poor in Manzini city is not bad. However, based on HFIAS Score many households are most severely food insecure. The inability to access food is further verified by their HDD Score value which was low (4.09), indicating very low levels of diversity in the diets where majorities ate cereals or food made from grains only. Such a low dietary diversity is likely to have negative health implications on the health of household members. The overall conclusion is that the majority of the Manzini urban poor are severely food insecure in terms of access based on HFIAS and HDD Scores.

Third, there are gender differences in the levels of household food security. Female headed and female centered households tended to be poorer than the other households and more severely food insecure. Furthermore, households which are severely food insecure tend to be very large or very small in size, and have a narrow range of livelihood strategies.

Fourth, the results of the survey show that household food insecurity has a temporal dimension, with April, May and December as better months while January, February, March, September and October as the worst months for the majority of households. The months of April and May coincide with the harvesting period when fresh food is more readily available.

Fifth, the results show that food sources in Manzini are relatively diverse. Purchases are a major source while own production is not an important source at all. The three main sources of food consumed by all types of households (classified according to income, size and tenancy type) are supermarkets, followed by purchases from small shop/restaurants/take away, and informal market/street food. Very few households got their food from food aid, remittances, urban agriculture, or neighbours. The fact that the majority of low-income urban households in Manzini purchase most of the food which they consume presents numerous problems since their irregular and paltry incomes are inadequate to pay for the varied and competing basic needs such as housing, education, transport and education.

Sixth, households which recorded illnesses and deaths were also the households that were moderately and severely food insecure. Also, ill health and death of a primary provider significantly reduced the household income. Ultimately, the impact of ill health and death was reduction of available labor and income which in turn affects the household's access to food. Most of the illnesses and deaths reported by the respondents were from AIDS or tuberculosis. These results reflect the national picture as the country has one of the highest HIV/AIDS prevalence rates in the world. What was also noted was that households are now quite open about reporting cases of AIDS and tuberculosis related illness, showing that stigma is no longer a hindrance.

Seventh, very few households received food in the past years from rural based relatives and friends and even fewer households received food from similar sources in urban areas. Contrary to what has been reported in the literature, in Manzini urban poverty has not strengthened urban-rural linkages in the form of increased food flows from rural to urban areas. The limited food flows from rural areas include roots, vegetables, fruits, meat/poultry and foods made from beans, peas, lentils or nuts. Most of these foods went to food insecure households.

Eighth, non-migrant households are more food secure than migrant households. On the other hand, the HDD score shows that migrant households have high dietary diversity than non-migrant households.

The findings are quite significant in many respects as they raise some policy implications for both the Manzini City Council and the Government of Swaziland. There is a need for government to specifically target urban households in addition to the focus on the rural areas. For example, the National Poverty Reduction Strategy and Action Programme (2006) and the various national action plans are clearly rural-biased. Government has to improve sustainable access to food. This can only be done if food production, processing and access are made part of a cohesive system. Thus, if the country can raise productivity of basic food commodities this can assist to lower consumer food prices thereby benefiting all groups that rely on income to buy food.

In addition, there is need to revisit the various national policies: population, food security and HIV/AIDS with a view to make direct links among these issues. For example, there is need to strengthen the safety nets for urban households who experience food insecurity and the strategies of how they cope in periods of hardship. Overall, there is an urgent need to improve the performance of the country's economy, especially through agriculture to lift people out of the cycle of poverty. The vulnerability of the low income populations in urban areas is now well understood and thus national policy must fully appreciate that poverty is the main driver of hunger

\section{ACKNOWLEDGEMENTS}

The authors thank the Urban Food Security Network for funding the study and the students of the Department of Geography, Environmental Science and Planning at the University of Swaziland for assistance 
with the fieldwork. The author is also grateful to Christa for assistance with data entry. Finally, and most of all, author would like to thank the Manzini residents who participated in the study and who took the time to share their experiences with author.

\section{REFERENCES}

[1]. Bouis, H. \& Hunt, J., (1999). Linking Food and Nutrition Security: Past Lessons and Future Opportunities Asian Development Review, vol. 17 nos. 1,2, pp. 168-213, Asian Development Bank

[2]. Braun, J. V. (2008). Taking action for the world's poor and hunger people, IFPRI, Beijing, China

[3]. Central Statistical Office (2008). Swaziland Demographic and health Survey 2006-07, Mbabane, Swaziland and Macro International Inc., Calverton, Maryland.

[4]. Crush, J., Frayne, B. \& Grant, M. (2006). Linking Migration, HIV/AIDS and Urban Food Security in Southern and Eastern Africa www.ifpri.org/renewal Accessed 16 February 2011

[5]. Crush, J., Hovorka, A. \& Tevera, D. (2010). Urban Food Production and household Food security in Southern African Cities, Urban Food Security AFSUN, series No. 4 Mega Digital, cape Town, South Africa

[6]. Dlamini, B. M. Simelane, K., Keregero, J. I. \& Dlamini, M. P. (2010). Perceptions of Framers Regarding Home Gardening in promoting Household Food Security in Swaziland, $22^{\text {nd }}$ Annual Conference Proceedings. Department of Agriculture Education and Extension, faculty of Agriculture, University of Swaziland, Swaziland pp163

[7]. Devereux , S.and Maxwell, S., (2001). "Introduction" In S. Devereux and S. Maxwell, eds., Food Security in Sub Saharan Africa (Pietermaritzburg: University of Natal Press, pp. 1-12.

[8]. Edje, O. T. (2010). Drought and food security in Swaziland. In Tevera, D. S. and Matondo J. I. (eds) Socio- economic development and the environment in Swaziland, GEP, Kwaluseni. pp. 130-151.

[9]. ECS. (2005). Common country assessment. Common Country Assessment - Swaziland, 1997.

[10]. Fall, A.S. (1998), Migrants' long-distance relationships and social networks in Dakar. Environment \&Urbanization 10(1): 135-145

[11]. Gama, T., (2006). Achieving the MDGs and Reducing Human Poverty www.undp.org.sz/poverty.htm. 17/02/2011

[12]. Government of Swaziland (2006). Poverty Reduction Strategies Action Plan, Ministry of Economic Development and Planning, Mbabane.

[13]. Government of Swaziland (2008), Swaziland, Annual Vulnerability Assessment and Analysis Report (2008): Mbabane, Swaziland

[14]. Jooma M. (2005). Southern Africa Assessment: Food Security and HIV/AIDS Africa Security Review 14, 59-66

[15]. Leedy, P. D. (1997). Practical Research; Planning and Design, Merrill Imprint of prentice Hall, USA

[16]. Mason B. (2006) Worsening food insecurity in Africa http://www.wsws.org/articles/2006/sep2006/hung-s06.shtml Accessed 12 November 2010

[17]. Ministry of Agriculture and Co-operatives (2006). National Programme for Food Security, Draft Report, MOAC, Mbabane, Swaziland

[18]. Mbuende, K. (1997). Secondary School Atlas, (3rd Ed). Cape Town: South Africa, Longman Publishers.

[19]. Potts, D and Mutambirwa, C, (1990). Rural-urban linkages in contemporary Harare: Why migrants need their land. Journal of Southern African Studies 16(4): 677-698

[20]. Tacoli, C. (2002), Changing rural-urban interactions in sub-Saharan Africa and their impact on livelihoods: a summary. London: International Institute for Environment and Development (IIED), Working Paper 7 on Rural-Urban Interactions and Livelihood Strategies

[21]. Tevera, D. S. \& Matondo J. I. (eds) (2010). Socio-economic development and the environment in Swaziland, GEP, Kwaluseni. pp. 153-74.

[22]. Tevera, D. S., Edge, O. T. \& Nkosi, B. S. (2010) Securing the future sustainable development issues as a policy priority in Swaziland Tevera, D. S. and Matondo J. I. (eds) Socio-economic development and the environment in Swaziland, Kwaluseni. pp. 385-391.

[23]. UNAIDS (2009). http://data.unaids.org/pub/FactSheet/2009/ Accessed 12 October 2010

[24]. USAID (1995). Food Aid and Food Security Policy Paper Washington, D.C.: USAID, Bureau for Program and Policy Coordination, (1995)

[25]. United Nations Development Programme (UNDP), (2006). Swaziland poverty report, United Nations, Mbabane

[26]. Webb, P., \& Rogers, B., (2003). Addressing the 'In' in Food Insecurity. Occasional Paper No. 1. USAID Office for Food for Peace, Washington, DC

[27]. World Food Programme (2009). Fighting Hunger Worldwide http://www.wfp.org/countries/swaziland. 17 February 2010.

[28]. World Food Programme (WFP). (2013). World Food Programme Fighting Hunger Worldwide. World Food Programme offices

[29]. Yasmin, H., Salam, A., Manyatsi, D. \& Tangutanazvo, D. B. (2010). The socio-economic impact of HIV/AIDS in Swaziland. In Tevera, D. S. and Matondo J. I. (eds) Socio-economic development and the environment in Swaziland, GEP, Kwaluseni Pp 325342 